\title{
Development of Flexible Dye-sensitized Solar Cell Based on Pre- dyed Zinc Oxide Nanoparticle
}

\author{
Liang Zhang, Akinori Konno* \\ Graduate School of Science and Technology, Shizuoka University, 3-5-1 Johoku, Hamamatsu, Japan \\ *E-mail: konno.akinori@ shizuoka.ac.jp
}

doi: $10.0964 / 2018.01 .07$

Received: 16 June 2017 / Accepted: 20 October 2017 / Online Published: 1 December 2017

Dye-sensitized solar cells (DSSCs) based on dyed zinc oxide ( $\mathrm{ZnO}$ ) nanoparticles made by simple predyeing method have been developed. Nanoporous $\mathrm{ZnO}$ film has been fabricated on transparent conducting oxide plastic polymer substrates. In order to improve lower porosity and bad interparticle connectivity, hot-press method was applied to pre-dyed $\mathrm{ZnO}$ film on the plastic substrate photoelectrode. The result that the hot-press treatment greatly improved the short circuit current of DSSCs based on pre-dyed $\mathrm{ZnO}$, indicates electrical contact of nanoparticles plays crucial role. In order to increase conversion efficiency, one of important points is how to enhance absorption of photon in wide wavelength region. We have successfully demonstrated that DSSCs based on two different kinds of pre-dyed $\mathrm{ZnO}$ composite film can expand absorption wavelength region and showed remarkable improvement of short circuit current.

Keywords: Pre-dyeing method, Hot-press treatment, Pre-dyed zinc oxide nanoparticle, Mixed dye sensitization, Flexible plastic substrate

\section{$\underline{\text { FULL TEXT }}$}

(C) 2018 The Authors. Published by ESG (www.electrochemsci.org). This article is an open access article distributed under the terms and conditions of the Creative Commons Attribution license (http://creativecommons.org/licenses/by/4.0/). 